\title{
ADMISSION TO PUBLIC LIBRARIES IN GREAT BRITAIN.
}

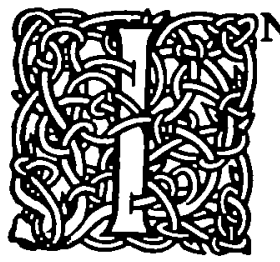

the interesting series of papers which have appeared in 'The Library,' 'How Things are Done in One American Library,' the writer, Mr. Crunden, refers to the terms upon which the public are admitted to the library. He says, "If security for the return of borrowed books is made the primary consideration, the usefulness of the institution is at once curtailed.' He then describes the very reasonable and easy terms upon which the people are allowed to use and to borrow books from the St. Louis Public Library. ${ }^{1}$

How do we stand in Great Britain in this matter? Have our public libraries done all that may reasonably be asked to make access easy and simple? It is not intended to discuss the question of admission to such libraries as the British Museum, the Guildhall Library, and others which are for reference purposes only, and where the restrictions imposed are only such as are necessary to keep the number of readers within the limits of the space available. It will be simpler and more profitable to deal with libraries established under the Public Libraries Acts, and containing as a rule three departments, viz., Reference Libraries, Reading Rooms for newspapers and periodicals, and Lending Libraries. With regard to the two first, the Reference Libraries and Reading Rooms, practically no restrietions are imposed; they are open to all, and no guarantees or references are asked for as a condition of admission.

The Lending Libraries, however, offer an entirely differ1 'The Library,' September, I 900, p. 385. 
ent set of circumstances. Here guarantees are asked for, and it may be useful to analyze the various methods, with the object of finding out whether the public are allowed such easy access to the books they pay for as is consistent with efficient administration and control.

The inquiries upon which the following observations are based were addressed to 367 public libraries, and replies were received from 308 . Of these about 20 were for various reasons of no value.

As a general rule, a householder whose name is on the voters' list, or on the rate book, is granted better terms than other residents, but the exceptions are rather numerous, for in eighty-five places voters and ratepayers use the library on precisely the same terms as other residents. This does not seem quite fair play for the people who directly contribute the funds out of which the library is supported. On the other hand there are eight places where only ratepayers whose names are on the voters' list are privileged to hold a borrower's ticket, an unnecessary restriction, which must prove inconvenient in the case of a large family, or where the person qualified declines to take out a ticket. One house one reader's ticket is happily not a general library rule, but it ought to be abolished altogether.

There is a growing feeling in the direction of allowing a ratepayer, as long as his name is on the current burgess roll or voters' list, to borrow books without a guarantor, provided he signs a form agreeing to abide by the rules. The returns give the following result:-Tickets issued to ratepayers without guarantee, 201 ; with one guarantor, 75 ; with two guarantors, I 5 . That is very satisfactory. But in the seventy-five places requiring one guarantor the subject might be reconsidered, and in the fifteen places requiring a ratepayer to provide two guarantors before he can borrow his own books some revision seems necessary.

Let us take next the persons who are not ratepayers, whose names do not appear in the voters' lists, and who 


\section{ADMISSION TO PUBLIC LIBRARIES}

presumably have not the same stake in the affairs of the library, but who nevertheless provide a large proportion of the readers. There are ten places which admit such persons without any guarantee, a liberality of practice which, though not perhaps generally possible, has yet proved satisfactory in several instances. Two other cases exist where all persons over twenty-one years of age are so admitted, while persons under twenty-one are required to provide security. Of the remaining returns, $24 \mathrm{I}$ require one guarantor, 30 require two, and 8 , as already stated, do not issue tickets to non-ratepayers. The qualification for a guarantor is usually that the name be enrolled on the current voters' list; in boroughe on the burgess list. Presumably where only one guaramer is required, the head of the family may become security tor all the members of his household, and there is therefore no hardship. The requirement of two guarantors is worthy of reconsideration, with a view to revision, if local circumstances will allow of it.

There is still another practice which has extended of late years, especially in London public libraries. Instead of obtaining the signature of one or two ratepayers to a guarantee form, an applicant may leave a money deposit. Ten shillings is the sum in most cases, and this is returned in full when the ticket is cancelled, or when the reader elects to substitute the usual guarantee agreement.

In nearly every instance the free loan of books is restricted to persons resident, rated, or employed within the library district, but in many cases persons not so qualified are allowed to use the library on payment of a small subscription annually, half-yearly, or quarterly. The amount ranges from one shilling per annum upwards. There are only a very few towns which admit all comers to the lending library without payment. This liberal policy must be impossible in many places. Yet if a good library attracts people from outside to the town to borrow books, those people will in most cases spend some money while in the 
town, to the increase of $i$. : trade. This aspect of the question may be worth thi. 'sing over.

One ticket is usually allowed to one person, but of late years the experiment of allowing an extra ticket for books other than fiction has been tried by some libraries. In towns having branch libraries, considerable trouble is taken to prevent a reader from holding a ticket for more than one library. There are exceptions to this. The more recent experiment is of considerable interest. A reader is allowed to hold a ticket for the central library, and for each branch if he or she desires, but no reader may use more than one ticket at one time at the central or any branch library. That is to say with a central and three branch libraries a reader may hold four tickets, provided he visits four libraries to obtain the loans. In practice it will be found that very few, if any, readers will take out more than two tickets, one for the nearest branch and one for the central library. From the branch he will obtain his supplies of recreative reading, using the central library for his other reading because of the wider choice of books. This seems to be a solution of the extra ticket question, which will work more satisfactorily than the earlier plan of concentrating the extra tickets at one library. It distributes the borrowing over two libraries or more, relieving the central from the extra work, and encouraging that concentration in one library of the best reading, which, as libraries develop in the larger towns, will become necessary if the stock of the more expensive books is not to be needlessly duplicated.

The restriction of the use of a ticket to the central library, or the particular branch for which it was issued, unless a formal transfer is applied for by the borrower, seems to be a needless interference with a reader's comfort. If the charging system requires the ticket to be kept in the library when a book is borrowed, there is no reason why the ticket may not be used at the central or any branch as the reader may find most convenient. As a rule 


\section{ADMISSION TO PUBLIC LIBRARIES}

readers will only use their tickets at the branch nearest to their homes. or their work, and the central library. The experiment of allowing tickets to be used at either the central or any branch at the reader's choice has been tried, and has not been found to present any difficulties. It saves trouble to the reader and to the staff.

Before leaving the subject of the admission of the public generally to the lending libraries, there are some exceptional practices which deserve mention, if only as examples of how not to do it.

Witnesses to the signatures of the guarantors and the readers are required in a few libraries, and in others children are not admitted unless the application forms are countersigned by a parent or a teacher. There is also at least one case where the privilege of signing a reader's application for a ticket is reserved for members of the library committee!

One other important test applied to the fitness of people to use a public library remains to be considered-the age at which borrowers are admitted to the lending libraries. A table will best summarise the result of the inquiries under this head:

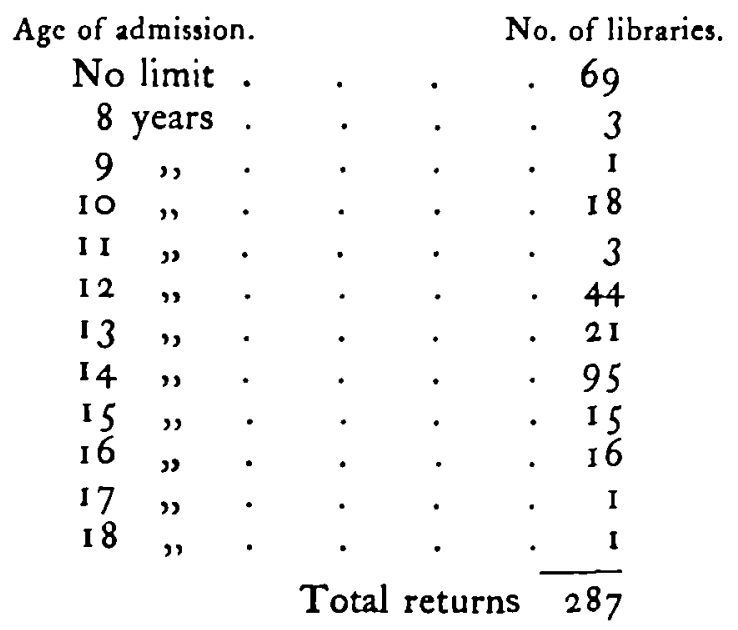


This table supplies much food for thought. The age limit, though fixed, is in many cases left to the librarian's discretion. In others, as already stated, the applications must be countersigned by a parent or teacher. The table supplies strong evidence that the limits have in many instances been fixed without full consideration, or in ignorance of the needs and the claims of children. In 128 districts having public libraries books are not lent to children under fourteen years of age. Seventy-six of these districts are towns each having over 20,000 inhabitants. The total population of the $\mathrm{I} 28$ districts at the last census was $5,127,565$ !

The principle of making easy the admission of children is extending. The value of the school-teachers as a factor in introducing children to the libraries is becoming more widely appreciated. The recommendation of teachers who are not saddled with any liability, is now being accepted in lieu of the guarantee of one or two ratepayers. In one instance at least-there may be others-the library supplies the head teacher of every school in the district, board or voluntary, elementary, higher grade, or intermediate, with a book of forms for recommending children as borrowers, and on these recommendations tickets are issued.

The admission of adults without guarantee, while children are required to provide security, as in the instance already quoted, is cautious but deterrent. So also are rules requiring the application forms to be countersigned by a parent or a guardian. Let us cease to be grandmotherly, and leave the control of the children and their habits to those who ought to control them. Our business is to make it easy for all to become readers. Let others impose the checks, if they wish their children not to read.

The returns show clearly that while there has been a considerable movement in the direction of simplifying admission to the libraries, yet many places lag behind. 


\section{ADMISSION TO PUBLIC LIBRARIES}

The terms of admission were originally formulated fifty years ago, when things were in an experimental stage. The imposition of restrictions designed to protect the books from theft and abuse may have been necessary then. At any rate they were thought to be. Experience has shown that the people may be trusted. If the library staff is efficient, there is nothing to fear from the public.

Three things suggest themselves as desirable: I. The abolition of the age limit for children; 2. The admission of residents who are not ratepayers on the guarantee of one ratepayer; 3. The admission of ratepayers without any guarantee except their own signatures.

The general adoption of these terms would remove a barrier which keeps many of the better class of readers from using the public libraries. Just imagine the case of a ratepayer who applies for the loan of a book, and who is handed a form with the request that he will obtain the signature of one, or possibly two, other ratepayers as a guarantee for the safe return of the book. He has to leave the building, get the form signed, and return to the library again before he can obtain the book. Two visits to the library, and one or more outside, before he can obtain the loan of a book worth perhaps six shillings. And he may be contributing many pounds per annum to the support of the institution. If the same person desires to introduce his wife, his son, his daughter, or his friend, the same difficulty occurs where two guarantors are required. It will be found that in the majority of cases the guarantee forms handed out to such persons are never returned, and the library suffers. 'Too much humbug!' is the short but expressive phrase of ten used to describe this antiquated red-tape system.

The risks are so small that it is folly to put the public to such mountains of labour. The number of visits prior to the admission of a person as a qualified borrower must be reduced to a minimum. No person presenting a form duly signed should be told to call the next day, or in two 
or three days, for a ticket. The ticket should be made out and a book delivered there and then.

It is the business of a rate-supported library to supply the ratepayers with books as simply and conveniently as possible consistent with the proper custody of the common property.

John Ballinger. 